\title{
RECALQUE EM SOLO DEVIDO À EXPLOTAÇÃO DE ÁGUA EM POÇO TUBULAR PROFUNDO
}

\author{
U.Duarte 1 \\ L.N.Menegasse ${ }^{2}$ \\ J.A.B.Sabadia ${ }^{2}$
}

No decorrer do $1^{\varrho}$ teste de bombeamento realizado no poço SABESP P6 (Parque Anhanguera-SP), observou-se o aparecimento de várias rachaduras nas paredes e muros das residências próximas ao local do poço motivando assim sua desativação. Devido sua excepcional vazão e objetivando avaliar as prováveis interações dos recalques produzidos no terreno devido sua explotação, um novo teste de bombeamento foi realizado nos dias 11 a 14 de dezembro de 1989, com o intuito de dimensionar o fenômeno ocorrido e caracterizar o regime hidráulico/dinâmico das formações aquifferas locais, bem como definir condições seguras de explotação do poço. $O$ ensaio de bombeamento/recuperação foi executado com vazões escalonadas de 70,90 e $142 \mathrm{~m}^{3} / \mathrm{h}$ durante períodos de 06, 12 e 07 horas, respectivamente, de bombeamento contínuo. Para caracterizar possíveis interferências entre o aquffero fraturado (cálcio-silicáticas/ anfibolitos do Grupo São Roque) e o aquffero freático local (08 metros de manto de intemperismo), foram perfurados 04 poços de observação P1 - 2,8m, P2-3,0m, P3 - 2,8m e P4 - 3,0 m. e aproveitados dois poços tipo cacimba, P5 4,0 m e P6 - 3,5m, existentes nas imediações do local de interesse. Foram tomadas medidas sistemáticas das aberturas das rachaduras existentes nas paredes de algumas construções vizinhas ao poço em teste, utilizando-se marcadores de posição e paquímetro com precisão de $0,01 \mathrm{~cm}$, antes, durante e após a conclusão do teste.

As dimensões das aberturas das fendas, inicialmente entre 2,1 e $24,0 \mathrm{~mm}$, oscilaram bastante durante todo o teste, embora situando-se dentro da faixa 0,1 a $3,1 \mathrm{~mm}$,

\footnotetext{
${ }_{1}^{1}$ Departamento de Geologia Econômica e Geofísica Aplicada, Instituto de Geociências, USP.

2Pós-graduação, Departamento de Geologia Econômica e Geofísica Aplicada, Instituto de Geociências, USP.
} 
aparentemente insignificante neste contexto, mas, fundamentais na interpretação do comportamento do solo quando analisados em conjunto com outros fatores. Estas fendas mostraram uma tendência sistemática a se abrirem (variação positiva). Observou-se também, que as maiores variações nas aberturas estão associadas às edificações mais intensamente abaladas (casas, 45, 112, 214 e 222). situadas à NW do poço bombeado $\theta$ onde estão concentrados os poços de observação que mostraram respostas mais rápidas ao bombeamento e posterior recuperação (rápidos decaimento e recuperação do N.A.). Este comportamento evidencia uma porção mais arenosa do aquffero freático local com condutividade hidráulica associada maior (paleocanal). As edificações mais abaladas estão assentes, portanto, neste trecho mais arenoso. A compactação de um aquffero arenoso raso como resposta ao rebaixamento induzido do nivel d'água se dá de forma imediata e inelástica, em função do aumento da tensão efetiva pela eliminação da pressão neutra com a retirada do líquido. Este recalque, como no caso ora comentado, é usualmente pequeno, restringindo-se ao rearranjo dos grãos minerais. Outro fator que pode ter corroborado para a ocorrência dos recalques diferenciados é a sobrecarga das pressões particulares das próprias fundações. Vale ressaltar aqui, que a má qualidade das estruturas das edificações (somente com amarração horizontal e inexistência de estacas de profundidade) contribuiu para destacar o fenômeno. Tendo em vista a finalidade do trabalho executado, constatou-se que não ocorreram evoluções significativas e que o solo encontra-se estabilizado. Para a exploração do poço recomendou-se a vazão de $90 \mathrm{~m}^{3} / \mathrm{h}$, cujo rebaixamento não compromete significativamente o nivel freático (N.A) local, resguardando-se assim o contexto hidrogeológico e das áreas construídas de fenômenos que porventura venham a ocorrer com rebaixamentos maiores do N.A. 